\title{
WHITMAN'S DREAM VISION: A Reading of "The Sleepers"
}

\author{
R. W. FRENCH
}

"The SleEPers" has LONG BEEN COUNTED among the more obscure poems of Leaves of Grass; it is, for example, the one poem that John Burroughs, who began reading Whitman in 1858 or 1859, singled out almost forty years later as being among those works in the Leaves he did not yet understand. ${ }^{1}$ Yet Whitman did much to make his meaning clear. "I wander all night in my vision," the poet proclaims at the start; after which he passes on a journey of the mind, making his way through varied experiences and recollections until he reaches a state of enlightenment that allows him to declare, without reservation, "The universe is duly in order, every thing is in its place" (1. 155). ${ }^{2}$ As much as any Whitman poem, "The Sleepers" moves purposefully toward a definite conclusion: the journey has meaning, and no stage of it is merely accidental. $^{3}$

Much of the critical uncertainty about "The Sleepers" can be resolved by recognizing its genre. Since the obvious is often overlooked, it is important that the obvious be stated: the poem is exactly what it appears to be, and what Whitman says it is in the opening line, a vision; more specifically, a dream vision. ${ }^{4}$ While it is not a definitive representative of dream vision, any more than "Song of Myself" is a definitive representative of epic, nevertheless it shares important attributes with such works as "The Dream of the Rood," "The Pearl," The Divine Comedy, The Romance of the Rose, "The Book of the Duchess," "The House of Fame," "The Parlement of Foules," The Vision of Piers Plowman, The Pilgrim's Progress, "The Triumph of Life," and "The Fall of Hyperion." While these works are so diverse that no generalization will readily apply to all of them, nevertheless it could be argued that the characteristic dream vision begins in confusion and ends in clarity; or at the very least that the dream experience significantly enhances the dreamer's understanding. Thus the dream vision may be perceived as something of a gift, a sign of favor, the granting of a boon that gives particular insight into essential matters and, in the most ambitious of the genre-The Divine Comedy of course comes to mind-into the center of the universe itself. In dream visions, then, the action that matters takes place within the dreamer's mind, which is left markedly changed by its experience. ${ }^{5}$

That "The Sleepers" should be regarded as particularly obscure is 
thus somewhat odd, for it has a clear plot much in the manner of dream visions. It begins with the poet in a state of confusion and distress: he describes himself as "Wandering and confused, lost to myself, illassorted, contradictory" (4). It ends, however, as noted above, with a vision of harmony, as the poet attains insight into a universe of perfect order. What appears to be accidental and random in this poem-the various recollections and episodes in their particular progression-turns out at the end to have been purposeful, for the sequence leads to illumination. The challenge for the reader is to follow the process that produces such desirable results. ${ }^{6}$

Right from the start of this dream vision the poet seems to attain god-like powers and a god-like perspective, as he moves through great spaces, observing the varied sleepers in their beds. We should expect no less; for in dream visions, as in dreams, one may be freed from the normal restrictions of the physical world. Existence becomes fluid, floating, immaterial. Thus the poet is free to wander where the spirit takes him, "Bending with open eyes over the shut eyes of sleepers, / . . . Pausing, gazing, bending, and stopping" $(3,5)$. His mind is released; but in its confused state it has nowhere to go, and so it goes everywhere, restless and perturbed.

What the poet sees in his wanderings reinforces the reader's sense of a soul in distress; for the people he visits in the night are so overwhelmingly among humanity's unfortunates that suffering and isolation would appear to be the norm, while happiness and love are rare exceptions, instances of good fortune that no one has any right to expect. ${ }^{7}$ If the poet's mind is disturbed, so is his perception of the world; nothing seems quite right. ${ }^{8} \mathrm{He}$ begins his wanderings by looking upon children, emblems of innocence and hope; but these children appear, if not quite dead, at least paralyzed or comatose: "How solemn they look there, stretch'd and still, / How quiet they breathe, the little children in their cradles" (6-7). There is no joy here, no delight in the possibilities of infancy, no Wordsworthian celebration of the child; the scene is curiously lifeless and numb.

Leaving the children, the poet then follows his mood to an array of death, disease, anguish, and suffering:

The wretched features of ennuyés, the white features of corpses, the livid faces of drunkards, the sick-gray faces of onanists,

The gash'd bodies on battle-fields, the insane in their strong-door'd rooms, the sacred idiots, the new-born emerging from gates, and the dying emerging from gates. . . . (8-9)

This passage-wholly appropriate to the speaker's uneasy state of mind-presents a sick and murderous world, where to be human is to be in hell; it is a vision worthy of Blake. The intrusion of the new-born 
into this appalling catalog has to be grimly ironic; for what sort of world are they being born into? An infant would ordinarily suggest hope for a new beginning, but the world we see at this point is hardly hopeful; rather, it is a place where the new-born appear less fortunate than the dying.

Restlessly moving on, the poet continues his wanderings; and for a moment the picture brightens as we turn in lines 11-14 to happy people: the married couple, the loving sisters, the men who "sleep lovingly side by side," the mother and child. Even here, however, there is a disturbing note, for these sleepers are threatened: helpless in their beds, they are observed as though by a voyeur-a voyeur, what's more, whom the reader knows to be agitated and disturbed. One may think of Milton's innocent Adam and Eve under the gaze of Satan: happy and loving these people may be, but we see them in an ominous context. Still, for a moment we have a glimpse of contentment, as the poet's mind shifts momentarily away from the darkness of life to a more fortunate realm of possibility; but then, as though to insist that such an idyllic picture is far from the measure of things, Whitman, having preceded this vision of happiness with one catalog of unfortunates, follows it with another:

The blind sleep, and the deaf and dumb sleep,

The prisoner sleeps well in the prison, the runaway son sleeps,

The murderer that is to be hung next day, how does he sleep?

And the murder'd person, how does he sleep?

The female that loves unrequited sleeps,

And the male that loves unrequited sleeps,

The head of the money-maker that plotted all day sleeps,

And the enraged and treacherous dispositions, all, all sleep.

The picture Whitman presents is of suffering, degradation, misfortune, and violence; again we have a series of life's victims, of outcasts and criminals, of the lonely and unsatisfied, the disturbed and distressed of this world. What is to be made of it all? There would seem to be no way out, for the poet's unhappy and unsettled mental state shapes his view of the creation; as Emerson noted in his essay "Nature," "The problem of restoring to the world original and eternal beauty is solved by the redemption of the soul," adding, two sentences later, "The reason why the world lacks unity, and lies broken and in heaps, is because man is disunited with himself." 9 If there is to be recovery, the integrity of the self must be restored; but so far the poem has given no indication of how that might be accomplished.

And yet, only three lines later, there is a dramatic sign of profound change as the poem leaps to new perceptions: 
Now I pierce the darkness, new beings appear,

The earth recedes from me into the night,

I saw that it was beautiful, and I see that what is not the earth is beautiful. (26-28)

The change recorded in this brief section is crucial, a clear turning point in the poem; and the explanation for it has to be in the three lines preceding these. In words that point prophetically toward Whitman's Civil War experience in the hospitals, the poet of "The Sleepers," looking upon the victims of life, responds with a sympathetic gesture:

I stand in the dark with drooping eyes by the worst-suffering and the most restless, I pass my hands soothingly to and fro a few inches from them,

The restless sink in their beds, they fitfully sleep. (23-25)

With these words, the poet moves toward the fulfillment that will come later in the poem when he has achieved peace within himself. ${ }^{10}$ Instinctively, spontaneously, at this point he shows compassion toward the unfortunate, and he gestures significantly, "soothingly," in an effort to ease their sufferings. His actions start the process that will bring him out of confusion and into clarity; immediately after making his sympathetic response, his perceptions change, as the world recedes and he gains insight into universal beauty. Sympathy, in short, leads to truth. Significantly, in a notebook fragment (perhaps dating as early as 1847) suggestive of the opening of "The Sleepers," Whitman implied the possibility of just such a process:

In the silence and darkness

Among murderers and cannibals and traders in slaves

Stepped my spirit with light feet, and pried among their heads and made fissures to look through

And there saw folded foetuses of twins like the foetuses of twins in the womb, Mute with bent necks, waiting to be born.-

And one was Sympathy and one was truth. ${ }^{11}$

Sympathy and truth: the two are one. If, however, the sympathetic gesture of "The Sleepers" seems too slight for its powerful effect, it might help to recall a comparable moment in "The Rime of the Ancient Mariner," when the Mariner, trapped in the isolation of his mind, alienated from nature, spontaneously blesses the water snakes: "A spring of love gushed from my heart," he tells the wedding guest, "And I blessed them unaware" (284-285). At this point, Coleridge's marginal gloss comments, "The spell begins to break," as the Albatross drops from the Mariner's neck and he finds that he can pray. ${ }^{12}$ The Mariner opens up new possibilities of the self; and in doing so he begins to rediscover, in Emerson's terms, the "original and eternal beauty" of the world that had been lost to him. 
The sympathetic gesture in "The Sleepers" is far from slight, for it indicates a profound change of mind-for the Romantic, the greatest change of all, since the mind's perceptions may be seen as acts of creation. It is as though the poet in this poem were discovering his true nature: to be, not an observer merely, but a healer. With this discovery he becomes, in effect, a new man in a new world; all relationships are altered. As a result of this self-fulfilling response, the poet's wanderings turn into a journey of discovery; like Dante in The Divine Comedy, as the poet of "The Sleepers" observes others, he is also making a voyage into the self-and from there, into the creation.

The initial discovery of the poet's sympathetic nature in "The Sleepers" suggests that of another great dream vision, Keats's unfinished "Fall of Hyperion," in which the poet is led to discover the true nature of his calling. As he seeks to ascend the steps leading to the shrine of the goddess Moneta, she admonishes him: "None can usurp this height,' returned that shade, 'But those to whom the miseries of the world / Are misery, and will not let them rest" " (147-149). As in "The Sleepers," it is compassion that must redeem the poet and give poetry a guiding purpose. When the poet in "The Fall of Hyperion" asserts, as though by rote rather than conviction, "sure a poet is a sage; / A humanist, physician to all men" (189-190), Moneta responds with an accusation. " "Art thou not of the dreamer tribe?," " she asks (198); and she goes on to make a crucial distinction between the dreamer and the poet:

"The poet and the dreamer are distinct,

Diverse, sheer opposite, antipodes.

The one pours out a balm upon the world, The other vexes it." $(199-202)^{13}$

"The Sleepers" begins with the poet as mere dreamer, caught up in his own confusions, powerless, unable to act or to respond sympathetically to the world about him. His isolation is extreme; it imprisons him within the self, depriving him of the largeness of experience necessary to full existence. At best he is only half alive. When he moves out toward a loving relationship, when he responds sympathetically to suffering, his mind expands into imaginative possibility; there is a sense of wondrous release, as confusion opens out into knowledge. ${ }^{14} \mathrm{He}$ begins, in short, to discover what it means to be a poet-or at least to be a poet such as Whitman would have, as envisioned most notably in "Song of Myself," but surely present in "The Sleepers" as well. By turning toward the needs of the suffering, the poet of "The Sleepers" leaves the self behind; and yet, perhaps paradoxically, by doing so he finds the means that liberate the self from bondage to its crippling sorrows and delusions. 
"The Universe," wrote Emerson in "The Poet," "is the externization of the soul." 15 Who would discover one must discover the other.

From its initial confusion and distress the poem now leaps into ecstasy. "I am a dance," the poet proclaims; "play up there! the fit is whirling me fast! / I am the ever-laughing . .." (32-33). Everywhere the poet sees energy and vitality coursing through life; all about him hover the "nimble ghosts" (34) who join him in boisterous conviviality: "Onward we move," he chants, "a gay gang of blackguards! with mirthshouting music and wild-flapping pennants of joy!" (41). Clearly, there has been a dramatic change of mood; in contrast to the sombre portrayal of life earlier in the poem, we turn now to uninhibited joy and abandon.

Confident, celebratory, as though overcome by his newlydiscovered powers of sympathy, the poet surges through other identities. "I am the actor, the actress, the voter, the politician," he proclaims (42). As he does so, however, a darker note begins to intrude. ${ }^{16}$ The initial enthusiasms turn out to have been premature and unearned; for the process of enlightenment is not yet complete. It lacks depth of understanding; there needs to be a firmer commitment to the complex and contradictory fullness of reality before it can be sustained. The poet's mind is not yet in a state to withstand the hostile pressures of experience; now, turning back to life's outcasts and unfortunates, he imagines himself "the exile, the criminal that stood in the box / . . the wasted or feeble person" $(43,45)$. The movement from joy back toward despair is psychologically right, as disillusion follows the fall from ecstasy; thus the poet's identification with the victims of life gains poignancy from the failed promise of hope.

Immediately after this identification, the poem appears to reverse itself, holding out the prospect of rapturous celebration as the poet becomes the woman whose lover has come: "I am she who adorn'd herself and folded her hair expectantly, / My truant lover has come, and it is dark" (46-47). Even here, however, there are ominous overtones. The lover is a "truant lover," unreliable and perhaps uncaring. The woman, so carefully adorned, appears vulnerable and exposed; and her role is largely passive, as she is the one who waits, who is received by the darkness and her lover, who resigns herself to the dusk, and who, at the end, follows and fades away.

Furthermore, this passage turns out to be not about the fulfillment of passion, but about its decline, if not its impossibility. There is anticipation of passionate love, and there is the falling away from it, but little is made of the actual experience, which is suggested only in retrospect, and then only in physical terms: "Darkness, you are gentler than my lover, his flesh was sweaty and panting, / I feel the hot moisture yet that he left me" (53-54). There is no sense of joy about the meeting, 
no rapturous outburst; rather, the woman appears to be used and abandoned. Not surprisingly, she turns to the darkness as substitute lover-a lover perhaps preferable for its gentleness:

He whom I call answers me and takes the place of my lover, $\mathrm{He}$ rises with me silently from the bed.

Darkness, you are gentler than my lover .... (51-53)

It may be that darkness is, finally, the only lover that matters, for darkness is inevitable: it can be trusted, for it will always be available, and it will turn no one away. In any case, the section ends (much like the "Ode to a Nightingale") in loss, and longing, and a sense of widening distance, as the woman fades away to emptiness. At the end she becomes yet one more representation of human life in all its transience and isolation.

In the subdued mood created by darkness and the sense of loss, the poet turns, not unnaturally, to thoughts of aging and of death, the ultimate loss. While he recognizes the claims of life-"It seems to me," he states, "that every thing in the light and air ought to be happy" (68) - still, the life he finds is marked above all by loss and separation and the fact of mortality. In the episodes that follow (Sections 3-6), the poet encounters life in its various sorrows. There are scenes of untimely death, as in the drowning of the "beautiful gigantic swimmer" (Section 3), the shipwreck (Section 4), and the slaughter of Washington's troops (Section 5); and there are scenes of sorrowful parting (Washington's farewell to his troops in Section 5, then the departure of the beautiful squaw in Section 6).

The first two episodes deal with isolated states: the solitary death of the swimmer and the solitary action of the poet who, although part of the crowd that searches the beaches and lays out the dead after the shipwreck, nevertheless remains alone, speaking to no one, addressed by no one. Both episodes deal with nature's violence, so inimical to human well-being; the mood is stark and sombre. Nothing is offered, not even companionship, to redeem the loss of life or to offset nature's wanton destructiveness. ${ }^{17}$ No attempt is made to justify the destruction or to place it in a larger context; it simply happens, apparently without reason or purpose, and humans are helpless before its overwhelming force.

Not surprisingly, as the poet moves from the drowned swimmer to the drowned victims of the shipwreck, he comments, "I turn but do not extricate myself, / Confused, a past-reading, another, but with darkness yet" (81-82). The confusion he began with has not yet been dispelled, although it is diminished in intensity and will eventually turn to confident knowledge. At this point, the confusion may be seen as a stage in 
growth. ${ }^{18}$ The sympathy the poet showed earlier was a move in the right direction, but it was not in itself sufficient; he must find the way to advance from a personal to a cosmic level, to see beyond the individual to the guiding forces that govern the universe. At this point the poem would appear to be moving farther into a state of mind dominated by thoughts of death and destruction; somehow the poet must find a way out, or else resign himself to a world dark beyond all consolation.

The next two episodes move toward the redemptive consolation that will raise the poem to new levels of insight. The first, with Washington as the central figure, speaks of loss and sorrow in the death of troops in battle, but it does not stop there; it goes on to recount Washington's farewell to his troops, thus providing an episode of masculine love-an episode, incidentally, that endures forever, because it is frozen in history: ${ }^{19}$

The officers speechless and slow draw near in their turns,

The chief encircles their necks with his arm and kisses them on the cheek,

He kisses lightly the wet cheeks one after another, he shakes hands and bids good-by to the army. (97-99)

The occasion is sad, but not beyond redemption, for it evokes a depth and intensity of feeling far beyond the ordinary. It gives dignity and stature to the men involved; there is nothing trivial or insignificant about this situation. The scene is far removed from the earlier visions of suffering and misfortune, for those began and ended with sordidness and degradation, suggesting only the meanness and injustice of life. In Washington's farewell to his troops, however, there is profound emotion; and there is nobility. In its simple dignity, the scene is almost Homeric; and it suggests, at the very least, that to be human is no small thing. By calling attention to the grandeur of human possibility, this scene effectively balances the earlier, darker representations of humanity.

The culminating episode-a prelude to the overwhelming vision of harmony that ends the poem-is that of the poet's mother and the "red squaw" who comes to her house for a few hours, then disappears forever. Like the preceding section, this is both a story of loss and a story of love. In counterpoint to the masculine love of Washington and his troops, this section presents the love of one woman for another:

My mother look'd in delight and amazement at the stranger,

She look'd at the freshness of her tall-borne face and full and pliant limbs,

The more she look'd upon her she loved her. . . . (106-108)

The episode goes beyond human love, however, for Whitman, with great subtlety and delicacy, careful not to press too hard, suggests that 
the squaw is, if not more than human, at least ideally human, an emblem of humanity at its finest. ${ }^{20}$ As the mother looked upon her visitor, Whitman wrote, "Never before had she seen such wonderful beauty and purity" (109). The squaw becomes one of Whitman's great primitives, comparable to "the friendly and flowing savage" of "Song of Myself" (Section 39) or the grand old man, the octogenarian "of wonderful vigor, calmness, beauty of person" in "I Sing the Body Electric" (Section 3). Like a Wordsworthian apparition, the squaw is perceived as an embodiment of nature, simple, pure, unspoiled, altogether beautiful. She may be one of the common people, no more than an itinerant mender of chairs, but in manner, appearance, and above all in the aura that surrounds her, she is extraordinary. She might be a goddess from Greek mythology, visiting one who only vaguely suspects her true identity, maintaining at all times her distance and her dignity, not returning the mother's love but silently accepting it as her due. She is taken into the house and treated with consideration and respect, and then she leaves, but she is not forgotten, as the mother senses that her visitor was out of the ordinary, a vision of nature's beauty and benevolence, and that she has somehow been specially favored. The squaw thus provides a corrective to the dark view of nature suggested by the drownings of Sections 3 and 4: she embodies a majestic serenity that endures beyond all destructive violence. To understand her, the poem hints, is to become wise.

After the squaw departs, it is as though a sign of blessing has been given. The mood of the poem brightens immediately, and all is made well. The Washington episode, with its demonstration of human love, prepared the way for this change, but it is the episode of the squaw, with its suggestion of an order and a beauty beyond the human, that finally shows a way out of the helpless despair of the two drowning episodes and moves "The Sleepers" into its great culminating vision. The poem now turns to joy, first sensed as a liberating impulse from the air:

A show of the summer softness-a contact of something unseen-an amour of the light and air,

I am jealous and overwhelm'd with friendliness,

And will go gallivant with the light and air myself. (117-119)

As in "Out of the Cradle Endlessly Rocking" and "When Lilacs Last in the Dooryard Bloom'd," nature itself favors the poet with direct communication. Coming at this point in the poem, the "contact of something unseen" opens the way to the final authoritative revelation. Hearing the murmurs of nature, and recognizing their benevolent intent, the poet is ready to go forth from darkness into light and air, and to go with a joyous heart. He knows now that all is complete and nothing is 
lacking; in "the dreams," he notes, there is "love and summer" as well as "autumn and winter" (120-121). The contraries are all part of the pattern. Whatever the vicissitudes of a human life, they are played out against a backdrop of purposeful, eternal recurrence, in which all moves toward eventual fruition: "The droves and crops increase, the barns are well-fill'd" (122).

What is true of nature and the day is true also of night. The world and its people move toward unity and reconciliation: night is the home toward which the varied creation tends. Clearly, by the end of the poem "night" has accumulated complex symbolic value. To say that it is death - the end of all that exists in a world of mutability-would be true, but only partially true, for it is more than that. ${ }^{21}$ Night is the force in nature that makes no distinctions, that functions as the great reconciler, that looks upon all creatures as equally valuable parts of an overwhelming unity, that says there is ultimately no loss, for in the end the pattern comes together, and nothing is missing. ${ }^{22}$ The culminating vision has to do with benevolence, harmony, and beauty:

The soul is always beautiful,

The universe is duly in order, every thing is in its place,

What has arrived is in its place and what waits shall be in its place. . . (154-156)

"The soul is always beautiful": appearance and situation may conceal the eternal, and one may see the part and ignore the whole; but when one has attained proper enlightenment-which is, after all, a concern central to much of Whitman's major poetry-one will see the reality of things as they are and endure with understanding life's difficult changes. Those who appeared earlier in the poem as representations of misfortune and suffering, including the "beautiful lost swimmer, the ennuyé, the onanist, [and] the female that loves unrequited" (133), now return to take their places in the cosmic pattern of harmony: "one is no better than the other, / The night and sleep have liken'd them and restored them" (142-143). To sleep, and then to die, is to join the ultimate harmony of eternity. This is not to say that suffering, sorrow, and death-all inherent in life-can be "explained," for they remain inexplicable; but they are not beyond redemption, for the ultimate force is seen to be one of benevolent order. While purposes may not be known, one may be confident in the final fitness of things. Nothing is lost that will not be restored. ${ }^{23}$

In the concluding section, the poet, like Plato's philosopher king, returns from the attainment of his vision to the light and life of day. Calmly he surveys the sleepers, as he did in the opening section, but there has been a dramatic shift in tone and attitude. Instead of a catalog of distress, we now have a catalog of reconciliation and restoration: 
The call of the slave is one with the master's call, and the master salutes the slave,

The felon steps forth from the prison, the insane becomes sane, the suffering of sick persons is reliev'd,

The sweatings and fevers stop, the throat that was unsound is sound, the lungs of the consumptive are resumed, the poor distress'd head is free,

The joints of the rheumatic move as smoothly as ever, and smoother than ever,

Stiflings and passages open, the paralyzed become supple,

The swell'd and convuls'd and congested awake to themselves in condition,

They pass the invigoration of the night and the chemistry of the night, and awake.

Seen from the viewpoint of eternity, the injustice and suffering of life become inconsequential and disappear; for what endures is the power that unifies and turns the many to one, the power that, like Dante's "L'amor che move il sole e l'altre stelle," or Spenser's great goddess Nature in "The Mutabilitie Cantos," or nature as it is perceived in Wordsworth's "Prelude" and "The Ruined Cottage" and various other poems, ultimately works toward tranquility, restoration, and harmony. It is this power that is represented by the night, that generative force at the center from which the poet came and to which he shall return, so to become part of eternity. "Why should I be afraid to trust myself to you?," he asks of the night (179), knowing now that the night means well by him and by all that lives; and thus he realizes that no matter how he may love "the rich running day" (181), with its action and variety, it is the night that in the concluding line he calls his "mother," and it is to the night, so loving and yet so mysterious, that he will return forever, for in night is gathered the beginning and the end of all creation.

\section{University of Massachusetts}

\section{NOTES}

1 John Burroughs, Whitman: A Study (Boston and New York: Houghton Mifflin, 1902), 3, 5. The poem's reputation for obscurity may explain the relative lack of attention it has received until quite recently-a neglect far out of proportion to its acknowledged value and interest. Scott Giantvalley's Walt Whitman, 1838-1939: A Reference Guide (Boston: G.K. Hall, 1981), contains two listings for the poem, both passing references in works centered elsewhere. There are twenty-four listings in Donald D. Kummings's Walt Whitman, 1940-1975: A Reference Guide (Boston: G.K. Hall, 1982), the earliest in 1955; almost all of these are brief notes on some aspects of the poem (like sources or influences) or discussions in a larger study of Whitman's poetry. No more than five of the articles listed could be considered detailed readings of the poem. The bibliographies in Walt Whitman Review and Walt Whitman Quarterly Review show about a dozen studies of "The Sleepers" in periodicals since 1975, with only a few extensive commentaries. In addition, there are comprehensive discussions of the poem in a number of books listed below, only one of which-Richard Chase's Walt Whitman Reconsidered-dates before 1966.

2 All quotations of Whitman's poetry are from Leaves of Grass, Comprehensive Reader's Edition, ed. Sculley Bradley and Harold W. Blodgett (New York: New York 
University Press, 1965). The text of "The Sleepers" used is that of the 1891-1892 impression of the final (sixth) 1881 edition of Leaves of Grass. While Whitman's revisions and deletions are of great interest, it is of course Whitman's final version that represents "The Sleepers" as he wanted it; and in any case that text remains the most widely available, despite the justifiable attention given to the 1855 poem.

3 As Mutlu Blasing rightly states in "'The Sleepers': The Problem of the Self in Whitman" (Walt Whitman Review, 21 [1975], 111-119), "The central metaphor of the poem . . . is a journey" (116). Blasing's analysis, however, is largely concerned with "The Sleepers" as a dream of "the visionary state of poetic creation" (118)-a valid and rewarding approach, surely, but one that differs markedly from the present study.

4 Harry James Cook, in "The Individuation of a Poet: The Process of Becoming in Whitman's 'The Sleepers' " (Walt Whitman Review 21 [1975], 101-110), accurately calls "The Sleepers" "a dream vision par excellence" (101-102); his reading of the poem, however, is strictly Jungian, according to his insistence that "Any valid interpretation of Whitman's poetry must be in large part autobiographical" (102). For a brief study of the poem based on the work of Jung's disciple Erich Neumann, see Michael Rainer, "Uroboric Incest in Whitman's 'The Sleepers,'" Walt Whitman Quarterly Review 1 (September 1983), 8-13. There is also considerable reliance on Jungian psychology in Robert E. Abrams, "The Function of Dreams and Dream-Logic in Whitman's Poetry," Texas Studies in Literature and Language 17 (1975), 599-616.

Rather than emphasize dream experience, R.W. Vince, in "A Reading of "The Sleepers" " (Walt Whitman Review 18 [1972], 17-28), discusses the poem in terms of the fiction of "mystical vision" (17). In the context of his discussion, however, "mystical vision" could as easily be called "dream vision." (Vince sometimes refers to the poem simply as a "vision.") In any case, there seems little to be gained for the present study by contesting the definition of "mystical"; and the issue is not a major concern for Vince's reading, which emphasizes the achievement of truth through the relationships of sexuality. As he notes, "the problem of death and evil [in 'The Sleepers'] is resolved through the expression in sexual images of the poet's gradually growing awareness of the truth of the underlying oneness of things" (18). While such a statement does not vary greatly from the understanding of the poem's destination asserted by this study, it differs significantly in its perception of the means by which the destination is reached.

In his brief comments on "The Sleepers," Harold Aspiz describes the poem as "a sustained dream vision in which the persona appears as a clairvoyant sleepwalker whose associate spirit, seemingly liberated from his body, communes without limitation with the spirits of men and women, living and dead" (Walt Whitman and the Body Beautiful [Urbana: University of Illinois Press, 1980], 172).

5 As Kerry C. Larson notes in Whitman's Drama of Consensus (Chicago and London: University of Chicago Press, 1988), "The Sleepers" is "the only poem in the 1855 edition which does not begin by calling on its auditors" (60). This feature of the poem emphasizes its interior nature: there is no audience to address, because the poem is focused within, in the manner of dreams.

6 The direction of this essay will differ markedly from what is probably the dominant interpretation of "The Sleepers," which explains the poem in Freudian terms as a representation of Oedipal conflict. See, most notably, Richard Chase, Walt Whitman Reconsidered (New York: William Sloane Associates, 1955), 54-57; Edwin H. Miller, Walt Whitman's Poetry: A Psychological fourney (Boston: Houghton Mifflin, 1968), 72-84; Stephen A. Black, Whitman's Fourneys into Chaos: A Psychoanalytic Study of the Poetic Process (Princeton: Princeton University Press, 1975), 125-137; and Ivan Marki, The Trial of the Poet (New York: Columbia University Press, 1976), 235-242. These readings make much, perhaps too much, of the deleted passages, especially the eleven 
lines beginning "O hot-cheek'd and blushing" (Leaves of Grass 626-627). While these extraordinary lines are accessible to psychological interpretations, they should not be overemphasized; and Whitman did, after all, delete them.

7 The emphasis should not be surprising, considering the poet's state of mind. As Donald Hall has observed in The One Day (New York: Ticknor \& Fields, 1988), "It's a commonplace of psychiatry that it may be useful, thinking about a dream, to consider that all of its characters are versions of the dreamer" (66).

8 In this respect one might compare "The Sleepers" to Robert Lowell's "Skunk Hour," another poem in which the speaker's confusion and distress - "My mind's not right," he admits - are reflected in his representations of a decaying, skewed world. "Skunk Hour," while not a dream vision, may be profitably compared to various works of the genre. Perhaps most significantly, its tableaux - so indicative of the poet's mind-end in the emblem of the skunks marching down Main Street, a vision suggesting some sort of order and purpose which may (or may not) be able to rescue the speaker from the threats posed by his own mind. See Life Studies (London: Faber and Faber, 1959), 61-62.

9 The Complete Works of Ralph Waldo Emerson, ed. Edward W. Emerson (Boston and New York: Houghton Mifflin, 1903), 1:73-74.

10 As Edwin H. Miller observes, "Almost at once a magical transformation takes place" (73). The magic is not, however, beyond explanation, as there is a clear change in mental posture behind the transformation.

11 Walt Whitman, Notebooks and Unpublished Prose Manuscripts, ed. Edward F. Grier (New York: New York University Press, 1984), 1:73. Additional notebook jottings that were revised into "The Sleepers" may be found among the entries in Walt Whitman, Daybooks and Notebooks, ed. William White (New York: New York University Press, 1978), 3:763-803. See also R.S. Mishra, "'The Sleepers' and Some Whitman Notes," Walt Whitman Quarterly Review 1 (June 1983), 30-36, and James Perrin Warren, "' 'Catching the Sign': Catalogue Rhetoric in 'The Sleepers,' "Walt Whitman Quarterly Review, 5 (Fall 1987), 16-34. Warren's main concern, as his title indicates, is with the catalogs of "The Sleepers"; but he also comments usefully on the origin and development of the poem as revealed in Whitman's notebooks.

12 The Complete Works of Samuel Taylor Coleridge, ed. Ernest Hartley Coleridge (Oxford: Clarendon Press, 1912), 1:198.

13 The Poems of Fohn Keats, ed. Jack Stillinger (Cambridge, Mass.: Harvard University Press, 1978), 481-483.

14 The theme of "The Sleepers," R.W. Vince has noted, is "the discovery of sympathy, or, in sexual terms, love as the key to the truth which transcends apparent evil . .." (18). One might add only that while the theme surely includes the transcendence of apparent evil, it extends far beyond that admittedly important concern-taking in, for example, the question of accident, or the apparent indifference of the universe, as well as the purposeful design that "evil" suggests.

\section{Complete Works, 3:14.}

16 The frantic quality of the poet's exuberance ought to arouse the reader's suspicions, perhaps suggesting that a fall is imminent. As Howard J. Waskow has noted, "If at the beginning of the poem the speaker is depressed, now he is manic-caught up in the wild, mad whirl of the imagination" (Whitman: Explorations in Form [Chicago and 
London: University of Chicago Press, 1966], 144). The manic phase leads back to depression; and at this point, Waskow observes, the poem must begin its journey once again (145).

17 "Death by Water," Whitman might have entitled these episodes, anticipating Section 4 of The Waste Land (T.S. Eliot, Collected Poems 1909-1962 [New York: Harcourt, Brace \& World, 1963], 65). If there is meaning to the death of Phlebas the Phoenician, it is surely comparable to the deaths of the beautiful gigantic swimmer and the victims of the shipwreck. In their deaths is prefigured the deaths of us all, for nature's purposes move toward annihilation: "Gentile or Jew / O you who turn the wheel and look to windward, / Consider Phlebas, who was once handsome and tall as you" (319-321). One might also compare the moods of three other great works involving death by water, Wordsworth's "Elegiac Stanzas," Melville's Moby Dick, and Crane's "Open Boat."

18 Howard J. Waskow's comment is helpful: "The confusion here is very different from the confusion in which he begins his journey. Then he is 'lost to [him]self' because he has not yet entered into the long night of experience-cannot, in fact, escape from himself and 'connect' to other life. Now, on the other hand, he is 'baffl'd' because he has seen too much, has learned that darkness holds death as well as love, and is therefore at once committed to the revelations of this new world and fearful of that commitment" (149).

19 Betsy Erkkila points out in Whitman the Political Poet (New York: Oxford University Press, 1989), 121, that both Washington passages in Section 5 of "The Sleepers" are based on descriptions in Joel Tyler Headley's Washington and His Generals (1847).

20 While the importance of the squaw is more than cultural, it is worth noting that there was considerable cultural significance in Whitman's time. As Betsy Erkkila has observed, "Like Washington, the squaw is a cultural icon. With her long black hair, tallborne face, beauty, and purity, she bears the traces of an iconographic tradition, dating back to the colonial period, in which America was represented as a native American woman" (122).

21 James E. Miller, Jr., comments that "the night symbolizes the world of spirituality, and sleep represents death's release of the soul" (A Critical Guide to Leaves of Grass [Chicago and London: University of Chicago Press, 1966], 130). While this reading is helpful-surely in some sense night and death have the symbolic values that Miller attaches to them -it may be overly restrictive, as the meanings that gather around night and sleep in the poem are more complex than any simple statement of equivalence would suggest.

22 In this respect "The Sleepers" is not dissimilar from "Song of Myself," a poem with which it is sometimes contrasted as a night-piece opposed to a day-piece, perhaps on the misleading analogy of Ulysses and Finnegans Wake. Both works find their way to assertions of ultimate order, the major difference being that "Song of Myself" loses its direction around the middle of the poem, when, in the "touch" crisis of Sections 27-28, the poet can no longer maintain rational control (e.g., line 638: "I talk wildly, I have lost my wits"), while "The Sleepers" is lost right at the start. Still, however circuitous the route, the two poems reach much the same destination: "The Sleepers" insists near the end that "The universe is duly in order, every thing is in its place" (155), while the poet of "Song of Myself" proclaims shortly before the close, "Do you see O my brothers and sisters? / It is not chaos or death-it is form, union, plan-it is eternal life-it is Happiness" (1317-1318).

23 Whitman's leap of faith at the end of the poem has caused problems. Kerry C. Larson, for example, finds that "the closer the poem draws toward a vision of restored 
union, the more tendentious and artificial its structure becomes" (70); and Betsy Erkkila writes that "Whitman's declaration of faith is a declaration by fiat. His assertion of unity is at odds with his confused and ill-assorted dream vision of a universe in which everything is not in order and diversity does not cohere" (124). It is important, however, to insist on the éssentially paradoxical nature of a transcendent faith that appears-but only, the believer would say, appears - to deny reality. However reason may protest, the authority of the vision is absolute and undeniable. 